\title{
A prospective randomized trial of imipenem-cilastatin versus clindamycin/tobramycin in the treatment of intra-abdominal and pelvic infections
}

\author{
lionel A Mandell, MD, frCPC, Pierre L Turgeon, MD, FrCPC, Allan R Ronalds, MD, FrCpC, \\ THE CANADIAN Clinical TrIaLS GROUP
}

\begin{abstract}
La Mandell, Pl Turgeon, ar Ronalds, The Canadian Clinical Trials Group. A prospective randomized trial of imipenem-cilastatin versus clindamycin/tobramycin in the treatment of intra-abdominal and pelvic infections. Can $J$ Infect Dis 1993;4(5):279-287.
\end{abstract}

\begin{abstract}
Oвлестіv: A Canadian multicentre clinical trial in the treatment of intra-abdominal and pelvic infections to compare the efficacy and safety of monotherapy using imipenem-cilastatin (imipenem) (500 $\mathrm{mg}$ intravenously every $6 \mathrm{~h}$ ) versus combination therapy with clindamycin/tobramycin (clindamycin $600 \mathrm{mg}$ intravenously every $6 \mathrm{~h}$ and tobramycin $1.7 \mathrm{mg} / \mathrm{kg}$ intravenously every $8 \mathrm{~h}$ ). Methods: Two hundred and fifty patients were entered ( 88 definite and 162 possible infections) and all were evaluable for analysis of adverse events and intention to treat analysis of efficacy. Dichotomous outcomes used were: cured versus noncured (improved, failed, relapsed). REsults: No statistically significant differences were found with the intention to treat analysis $(\mathrm{P}=0.88)$ or with definite infections $(\mathrm{P}=0.81)$. For overall bacteriological response, no significant differences were noted $(\mathrm{P}=0.1)$. Eleven and 15 patients on imipenem and clindamycin/ tobramycin, respectively, were colonized with bacteria. Enterococci colonized four of 11 imipenem cases and five of 15 clindamycin/tobramycin cases while fungi colonized six patients on imipenem and four on clindamycin/tobramycin. Five patients on imipenem and seven on clindamycin/tobramycin developed superinfection. In the imipenem group, one case had a bacterial superinfection while four cases were due to Candida albicans. Seven of seven superinfections on clindamycin/tobramycin were bacterial. Three bacteria initially sensitive to the assigned study drug developed resistance. In two patients on imipenem, Enterococcus faecalis and Pseudomonas aeruginosa became resistant after 14 and 10 days of therapy, respectively. On clindamycin/tobramycin, one instance of Bacteroides fragilis resistance after eight days of therapy was seen. Eighty-three adverse events occurred; 47 in the imipenem group and 36 in the clindamycin/tobramycin group. This resulted in discontinuation of antibacterial therapy in 13 patients, seven of whom were on imipenem and six on clindamycin/tobramycin. Comparison of adverse effects showed statistically significant differences for nausea $(\mathrm{P}=0.02)$ and hepatotoxicity $(\mathrm{P}=0.05)$ occurring with greater frequency in the imipenem and clindamycin/tobramycin groups, respectively. ConcLusions: These data support the conclusion that monotherapy with imipenem (500 mg intravenously every $6 \mathrm{~h}$ ) is as efficacious as clindamycin/tobramycin for treatment of intra-abdominal and pelvic infections. Both regimens are well tolerated. (Pour résumé, voir page 280)
\end{abstract}

Key Words: Imipenem-cilastatin, Intra-abdominal infections

Division of Infectious Diseases, Department of Medicine, Henderson General Hospital and McMaster University, Hamilton, Ontario; Service of Microbiology and Infectious Diseases, Hôpital Saint-Luc and l'Université de Montréal, Montréal, Québec; and Department of Medicine and Medical Microbiology. The University of Manitoba, Winnipeg, Manitoba

Correspondence and reprints: Dr Lionel A Mandell, McMaster Medical Unit, Henderson General Hospital, 711 Concession Street, Hamilton, Ontario L8V 1C3. Telephone (416) 574-8520

This paper was presented at the 31st Interscience Conference on Antimicrobial Agents and Chemotherapy, Chicago, Ilinois, October 1991

Received for publication August 24, 1992. Accepted December 24, 1992 


\title{
Essai prospectif randomisé de l'imipénème-cilastine versus clindamycine/ tobramycine dans le traitement des infections intra-abdominales et pelviennes
}

\begin{abstract}
OвJестіF: Essai clinique multicentrique canadien sur le traitement des infections intra-abdominales et pelviennes visant à comparer l'efficacité et l'innocuité d'une monothérapie à base d'imipénème-cilastatine (imipénème) ( $500 \mathrm{mg}$ par voie intraveineuse aux $5 \mathrm{~h}$ ) versus un traitement d'association à base de clindamycine/tobramycine (clindamycine $600 \mathrm{mg}$ par voie intraveineuse et trobramycine $1,7 \mathrm{mg} / \mathrm{kg} \mathrm{par}$ voie intraveineuse aux 8 h). MérHodes: Deux cent cinquante patients ont été inscrits (88 cas avérés et 162 soupçonnés) et ils ont tous été jugés évaluables au fin d'analyse des incidents défavorables d'analyse de l'efficacité dans l'intention de traiter. Les résultats dichotomiques utilisés ont été les cas guéris versus non guéris (amélioration, échec, rechute). RÉsultats: Aucune différence statistiquement significative n'a été observée au plan de l'analyse de l'intention de traiter $(\mathrm{P}=0,88)$ ni au plan des infections avérées $(\mathrm{P}=0,81)$. Pour la réponse bactériologique globale, aucune différence significative n’a été observée $(\mathrm{P}=0,1)$. Onze et 15 patients sous imipénème et clindamycine/tobramycine respectivement, ont présenté une colonisation bactérienne. Les entérocoques ont colonisé quatre des 11 cas sous imipénème et cinq des 15 cas sous clindamycine/tobramycine, alors que des mycoses ont été observées chez six patients sous imipénème et quatre sous clindamycine/tobramycine. Cinq patients sous imipénème sept patients sous clindamycine/tobramycine ont développé une surinfection. Dans le groupe imipénème, un cas a présenté une surinfection bactérienne alors que quatre autres étaient dus à Candida albicans. Les sept cas de surinfection sous clindamycine/tobramycine étaient bactériens. Trois bactéries, au départ sensibles au médicament assigné dans le cadre de l'étude, ont développé une résistance. Chez deux patients sous imipénème, Enterococcus faecalis et Pseudomonas aeruginosa sont devenus résistants après 14 et 10 jours de traitement respectivement. Une occurrence de Bacteroides fragiles résistant a été observée après huit jours de traitement à la clindamycine/tobramycine. Quatre-vint-trois réactions défavorables ont été déclarées, 47 dans le groupe imipénème, et 36 dans le groupe clindamycine/tobramycine. Cela a forcé l'interruption du traitement antibactérien chez 13 patients dont sept étaient sous imipénème et six sous clindamycine/tobramycine. Une comparaison des effets secondaires a révélé des différences statistiquement significatives pour ce qui est de la nausée $(\mathrm{P}=0,02)$ et l'hépatotoxicité $(\mathrm{P}=0,05)$, la fréquence en étant plus élevée respectivement dans le groupe imipénème et dans le groupe clindamycine/tobramycine). Conclusions: Ces résultats appuient la thèse selon laquelle la monothérapie avec imipénème (500 mg par voie intraveineuse aux 6 h) est aussi efficace que la clindamycine/tobramycine dans le traitement des infections abdominales et pelviennes. Les deux schémas thérapeutiques sont bien tolérés.
\end{abstract}

$\mathrm{I}$ NTRA-ABDOMINAL AND INTRAPELVIC INFECTIONS ARE TYPIcally polymicrobial in nature. The organisms encountered are unpredictable and may be Gram-positive or Gram-negative, aerobic or anaerobic. The drugs selected for therapy of such infections must provide broad coverage (1-4). The anaerobic pathogens encountered at these sites include anaerobic cocci, Bacteroides species and Clostridium species, while the aerobic pathogens include hemolytic and nonhemolytic streptococci as well as many of the Enterobacteriaceae $(4,5)$.

Recognizing the mixed nature of these infections, conventional treatment has usually been with an aminoglycoside plus an antimicrobial such as clindamycin or metronidazole, which is directed specifically against anaerobes (6-8). While effective, such standard regimens still use two drugs. The nephrotoxic potential of aminoglycosides, particularly in patients who are seriously ill, is a concern and requires monitoring of serum levels and occasional adjustment of dosing intervals (9).

Imipenem is a carbapenem antibiotic with the broadest antibacterial spectrum of any of the currently available beta-lactam drugs $(10,11)$. It is active against most clinically significant Gram-positive species including the enterococci, most Gram-negative species and anaerobes (10,11). Imipenem is always administered jointly with cilastatin, which inhibits inactivation of imipenem by a renal brush border enzyme dehydropeptidase 1 , and eliminates any renal tubular toxicity of imipenem (12).
Because of its broad spectrum of activity, this unique compound offers the potential for monotherapy of intra-abdominal and pelvic infections. To test this hypothesis, a prospective randomized controlled trial was carried out to determine the efficacy and toxicity of imipenem versus clindamycin/tobramycin for treatment of such infections.

\section{PATIENTS AND METHODS}

Study design: The study was a multicentre randomized controlled trial carried out in 19 university medical centres across Canada. Patients who satisfied the inclusion criteria and provided written informed consent were randomized to one of two treatment regimens: imipenem $500 \mathrm{mg}$ intravenously every $6 \mathrm{~h}$ with an equal quantity of dehydropeptidase inhibitor; or the combination regimen of clindamycin $600 \mathrm{mg}$ intravenously every $6 \mathrm{~h}$ and tobramycin $1.7 \mathrm{mg} / \mathrm{kg}$ every $8 \mathrm{~h}$. Random assignment to the treatment arms was done in each participating centre by the investigator using previously prepared sealed envelopes containing the treatment codes. The randomization process was based on computer generated numbers.

Inclusion criteria: Male and female hospitalized patients at least 16 years of age with any of the following infections were included in the study: subphrenic or other intraperitoneal abscesses; appendiceal, liver or other intravisceral abscesses; acute cholangitis; acute cholecystitis; empyema of the gall bladder; acute peri- 
tonitis; acute diverticulitis with or without abscess formation; perianal abscess with or without fistula formation; and gynecological infections including endomyometritis, septic pelvic thrombophlebitis, pelvic peritonitis, salpingo-oophoritis, pelvic cellulitis, pelvic abscess, septic abortion and intrapelvic infection following pelvic surgery.

Patients with intra-abdominal infections were required to meet any two of the following criteria with at least one pertaining to the abdomen: abdominal tenderness; fever greater than $38.5^{\circ} \mathrm{C}$ on two occasions at least $4 \mathrm{~h}$ apart unrelated to drugs or blood products; the presence of a new mass in the abdomen; findings of peritonitis such as guarding and rebound tenderness and diminished bowel sounds; or rigors regardless of temperature.

Patients with intrapelvic infections were required to meet any two of the following criteria with at least one pertaining to the pelvis: adnexal mass; pain on cervical manipulation; fever greater than $38.5^{\circ} \mathrm{C}$ on two occasions at least $4 \mathrm{~h}$ apart unrelated to drugs or blood products; rigors regardless of temperature; or findings of peritonitis such as guarding and rebound tenderness and diminished bowel sounds.

Patients were classified as having infections in these various sites if they had signs and symptoms of an infection referable to the site as described above in conjunction with an elevated total leukocyte count (greater than $10,000 / \mathrm{mm}^{3}$ ). Blood samples for culture purposes were obtained from all patients as well as cultures of suspected infection sites. Additional confirmatory studies such as roentgenograms, ultrasounds, computed tomography scans and nuclear imaging tests were done when necessary.

For the purposes of data analysis, patients were classified as having either a definite or a possible infection. Possible infections were those in which there was clinical evidence of infection in a specific site (abdomen or pelvis) without corroborating microbiological data. Patients with definite infections had both clinical and microbiological documentation of infection.

Exclusion criteria: The following patients were excluded from the study: patients younger than 16 or older than 75 years of age; patients with a high probability of death within $48 \mathrm{~h}$; patients who were neutropenic (less than 1000 cells $/ \mathrm{mm}^{3}$ ); patients who were anuric or who had serum creatinines greater than $144 \mu \mathrm{mol} / \mathrm{L}$; patients who had an immediate type reaction to any of the beta-lactam antibiotics (cephalosporins, penicillins, cefamycins) or who were hypersensitive to imipenem-cilastatin or to clindamycin/tobramycin; patients who had received effective antimicrobial therapy active against some or all of the infecting pathogens within $72 \mathrm{~h}$ of the proposed initiation of this study; pregnant women and nursing mothers; patients whose primary infecting pathogen was known or presumed to be resistant to imipenem or to either clindamycin or tobramycin before entry into the study; or classic pelvic inflammatory disease for which chlamydia may be a pathogen.

Clinical and laboratory evaluation: Before starting therapy, each patient underwent a complete history and physical examination. The investigators rated the patient's underlying disease according to the McCabe Jackson criteria as nonfatal, ultimately fatal or rapidly fatal (13). The following laboratory studies were done immediately before beginning antibiotic treatment, four to seven days after onset of therapy, and one to three days after conclusion of therapy: hemoglobin, hematocrit, white blood cell count and differential, platelet count, blood urea nitrogen, serum creatinine, alanine aminotransferase, aspartate aminotransferase, alkaline phosphatase, bilirubin, prothrombin time, Coombs' test, serum electrolytes and routine and microscopic urinalysis. If treatment was continued into the second or third week, additional tests were repeated between days 9 and 11 and days 15 to 17 , respectively. X-rays and other imaging studies were done as required for documentation of infection in individual patients according to the site involved.

Cultures of suspected infection sites were obtained before the start of drug therapy. Gram stains of specimens from all known or suspected sites of infection were routinely obtained. Follow-up cultures of blood were obtained as often as necessary during and after therapy with the study drugs. Where possible, any patient who was not clearly responding to treatment had follow-up cultures from the primary infected site $48 \mathrm{~h}$ after the start of therapy. Where appropriate, all patients also had test of cure cultures two to four days after the conclusion of drug therapy.

All cultures were processed using standard methods in the microbiology laboratories at the university teaching hospitals taking part in the study. Susceptibility of the isolates to the test drugs was determined using standard disc susceptibility methods (14). For the study drugs, the following disc potencies were used: imipenem, $10 \mu \mathrm{g}$; clindamycin, $2 \mu \mathrm{g}$; tobramycin, $10 \mu \mathrm{g}$. Organisms were considered resistant to these drugs if zone sizes were less than or equal to $13 \mathrm{~mm}, 14 \mathrm{~mm}$ and $12 \mathrm{~mm}$, respectively. Susceptibility testing of anaerobic organisms was done at Hôpital Saint-Luc in Montreal, Quebec using an agar dilution method with Wilkins-Chalgren agar (15).

Drug administration: Following randomization, the study drugs were reconstituted with sterile water. Those randomized to receive imipenem-cilastatin were given $500 \mathrm{mg}$ of each every $6 \mathrm{~h}$. Those randomized to clindamycin/tobramycin received $600 \mathrm{mg}$ of clindamycin intravenously every $6 \mathrm{~h}$ and $1.7 \mathrm{mg} / \mathrm{kg}$ of tobramycin intravenously every $8 \mathrm{~h}$. All infusions were given over 20 to 60 mins. Blood samples for determination of tobramycin levels were obtained 30 mins pre- and postdosing on the second or third, fourth or sixth and last day of therapy. Peak values were adjusted to levels 
between 4 and $8 \mu \mathrm{g} / \mathrm{mL}$, and trough values to less than $2 \mu \mathrm{g} / \mathrm{mL}$.

A minimum treatment period of five days was required for inclusion of cases in the standard analysis of efficacy. For the 'intention to treat analysis of efficacy', all randomized cases were included regardless of duration of treatment.

Evaluation of responses: Patients were evaluated to determine both the efficacy and toxicity of the two treatment regimens. Efficacy was determined by assessing both the clinical and bacteriological responses. Clinical response was classified as follows: cured clinical findings subsided in a reasonable period of time with no evidence of active infection when the treatment drug was discontinued; improved - clinical findings subsided significantly in a reasonable period of time but with incomplete resolution of evidence of infection; failure - no apparent response to therapy; relapse - patient presented within seven days of termination of drug treatment with similar clinical findings and the same pathogen was isolated; indeterminate - any reason for which the investigator found it impossible to evaluate the results.

Bacteriological responses were classified as follows: eradication of the organism(s) from culture sites; elimination with recurrence; persistence of the organism(s).

Two additional outcome measures were: colonization with new organisms, and superinfection. Colonization was defined as the appearance of any potentially pathogenic organism(s) in cultures obtained after starting therapy but without signs or sympoms of infection. Superinfection was defined as the development of fever or other clinical evidence of infection accompanied by the presence of a new infecting organism.

The adverse events monitored during the study were: hypersensitivity reactions; nephrotoxicity; nausea; vomiting; diarrhea; pseudomembranous colitis; hepatotoxicity; prolongation of the prothrombin time of at least $2 \mathrm{~s}$ above the control value; appearance of a positive Coombs' test with or without hemolysis; local intravenous site complications; dizziness; headache; vertigo; and seizures. Intravenous site complications included cellulitis, phlebitis, and burning or pain upon drug administration. The documented adverse reactions were assessed by the investigator for severity (fatal, severe, moderate or mild) and relationship to the study drug (definite, probable or unlikely).

Nephrotoxicity was defined as an increase in the serum creatinine of greater than $44 \mu \mathrm{mol} / \mathrm{L}$ if the initial creatinine value was less than $265 \mu \mathrm{mol} / \mathrm{L}$ (16). Nephrotoxicity was 'definite' if no other cause of acute renal failure was identifiable within $72 \mathrm{~h}$ of the change in serum creatinine. Hepatotoxicity was defined as a twofold elevation of any liver function tests above the upper limit of normal, and a twofold elevation of the baseline value if pretreatment levels were beyond the normal range. As with nephrotoxicity, any other factors that might cause impairment of liver function were considered.

Data analysis: Patient entries were reviewed by a blinded adjudicating committee. An intention to treat analysis and analysis of definite infections were carried out as well as an analysis of adverse drug reactions. Major protocol violations were excluded from the analysis of definite infections only. Using the outcome measures described above, analysis of efficacy and drug toxicity data as well as demographic characteristics of the patients in the two treatment groups was done using the $\chi^{2}$ statistic for comparison of proportions in independent samples. In all cases where numbers were such that calculated expected values in any cell were less than 5, the Fisher's exact test was used. For multiple comparisons of paired data, the Bonferroni correction was applied. All reported P values are two-tailed and the criterion for statistical significance was a $\mathrm{P}$ value less than 0.05. In addition to tests of significance, comparisons of proportions were also made by determining the $95 \%$ confidence limits on the differences in population proportion success.

\section{RESULTS}

Characteristics of the study population: A total of 250 patients was entered into the study over an 18 month period. All cases were evaluable for analysis of adverse drug effects and intention to treat analysis of efficacy. Definite infections were present in 88 of the 250 cases and possible infection in 162 cases. The 125 patients in the imipenem group included 41 with definite infections and 84 with possible infections. The 125 patients receiving clindamycin/tobramycin included 47 with definite and 78 with possible infections.

Demographic and prognostic characteristics of the patients in the two study groups were examined and no significant differences were noted (Table 1).

The distribution of pathogenic bacteria at the initial sites of infection among the patients in the study arms was evaluated in terms of total organisms per treatment group and according to site of infection in each treatment group. Table 2 lists the pathogenic bacteria in the 88 patients with definite infections. The most common aerobic Gram-positive coccus was nonenterococcal streptococci. The most common aerobic Gram-negative bacilli in order of decreasing frequency were Escherichia coli and Klebsiella species. Bacteroides fragilis was the most common anaerobic organism found.

Twenty cases were associated with bacteremia, eight in the imipenem arm and 12 in the clindamycin/tobramycin arm. In the imipenem arm, $E$ coli bacteremia occurred in two patients, $B$ fragilis in two patients, and Bacteroides species, Clostridium species and Salmonella species in one patient each. One patient had polymicrobial bacteremia with Enterococcus faecalis and Klebsiella pneumoniae. Seven of the eight patients were cured and one improved. 
TABLE 1

Demographic and prognostic characteristics of 250 evaluable cases

\begin{tabular}{|c|c|c|}
\hline \multirow[b]{2}{*}{ Characteristic } & \multicolumn{2}{|c|}{ Patients treated with } \\
\hline & $\begin{array}{l}\text { Imipenem- } \\
\text { cilastatin } \\
(n=125)\end{array}$ & $\begin{array}{c}\text { Clindamycin/ } \\
\text { tobramycin } \\
(n=125)\end{array}$ \\
\hline Sex (male/female) & $60 / 65$ & $56 / 69$ \\
\hline \multicolumn{3}{|l|}{ Age (years) } \\
\hline Range & $14-84$ & $16-84$ \\
\hline Mean & 49.4 & 47.8 \\
\hline \multicolumn{3}{|c|}{ Duration of treatment (days) } \\
\hline Range & $1-21$ & $1-19$ \\
\hline Mean & 7.1 & 8.5 \\
\hline Standard deviation & 4.1 & 3.6 \\
\hline Concomitant disease* & 143 & 137 \\
\hline \multicolumn{3}{|l|}{ Infection site } \\
\hline Intra-abdominal $^{\dagger}$ & 106 & 106 \\
\hline Intrapelvic ${ }^{\dagger}$ & 19 & 19 \\
\hline \multicolumn{3}{|c|}{ McCabe Jackson rating of underlying disease } \\
\hline Nonfatal & 99 & 98 \\
\hline Ultimately fatal & 9 & 11 \\
\hline Rapidly fatal & 3 & 3 \\
\hline Unknown & 14 & 13 \\
\hline
\end{tabular}

- Concomitant diseases include cardiovascular, resplratory, neoplastic, cerebrovascular, gastrointestinal, metabolic, renal, hepatic, connective tissue, and alcohol or other drug abuse. The number of concomitant diseases exceeds number of patients treated because some patients had more than one concomitant illness. IIntra-abdominal infections include: abscess - imipenem 32, clindamycin/tobramycin 28; peritonitis - imipenem 26, clindamycin/tobramycin 26; biliary tract-imipenem 26 , clindamycin/tobramycin 17; intestinal/colonic-imipenem 24, clindamycin/tobramycin 30; miscellaneous - imipenem 2, clindamycin/tobramycin 5. Fintrapelvic infections include: abscess - imipenem 3, clindamycin/tobramycin 5; parametritis/endomyometritis - imipenem 16. clindamycin/tobramycin 13; miscellaneous - imipenem 0, clindamycin/tobramycin 1

In the clindamycin/tobramycin arm, $E$ coli bacteremia occurred in two patients, peptostreptococci in two patients, and anaerobic Gram-positive cocci without further identification were found in another patient. Episodes of bacteremia were documented in individual patients with the following organisms: $B$ fragilis, Bacteroides species, K pneumoniae, Salmonella enteritidis, and alpha-hemolytic streptococci. Two patients had polymicrobial bacteremia; one with $K$ pneumoniae and Proteus species, and one with Streptococcus viridans and peptostreptococci. Nine of the 12 patients were cured and three failed. The three failures were in patients with $B$ fragilis, Bacteroides species and one patient with $K$ pneumoniae and Proteus mirabilis,

Clinical and bacteriological responses: The outcome measures for clinical response are given in Table 3. For assessment of the clinical endpoints, two separate analyses were done. The first considered all patients entered into the trial (intention to treat analysis), while the second dealt only with patients with definite infections. For these analyses, the dichotomous outcomes cured versus noncured (improved, failed, relapsed) were
TABLE 2

Pathogenic bacteria in 88 patients with definite infections

\begin{tabular}{|c|c|c|}
\hline \multirow[b]{2}{*}{ Organism } & \multicolumn{2}{|c|}{ Patients treated with } \\
\hline & $\begin{array}{l}\text { Imipenem- } \\
\text { cilastatin } \\
(n=41)\end{array}$ & $\begin{array}{c}\text { Clindamycin/ } \\
\text { tobramycin } \\
(n=47)\end{array}$ \\
\hline \multicolumn{3}{|l|}{ Gram-positive aerobes } \\
\hline Staphylococcus aureus & 6 & 1 \\
\hline $\begin{array}{l}\text { Streptococcus species } \\
\text { (nonenterococcal) }\end{array}$ & 22 & 30 \\
\hline Enterococci & 10 & 20 \\
\hline Others & 0 & 1 \\
\hline \multicolumn{3}{|l|}{ Gram-negative aerobes } \\
\hline Escherichia coli & 48 & 52 \\
\hline Klebsiella species & 7 & 20 \\
\hline Enterobacter species & 3 & 5 \\
\hline Proteus species & 2 & 13 \\
\hline Citrobacter species & 4 & 0 \\
\hline Acinetobacter species & 3 & 0 \\
\hline Pseudomonas aeruginosa & 6 & 8 \\
\hline Pseudomonas species & 2 & 0 \\
\hline Salmonella species & 1 & 2 \\
\hline Others & 1 & 4 \\
\hline \multicolumn{3}{|l|}{ Anaerobes } \\
\hline Bacteroides fragilis & 13 & 27 \\
\hline Bacteroides fragilis group & 12 & 17 \\
\hline Clostridium species & 4 & 12 \\
\hline Fusobacterium species & 2 & 5 \\
\hline Peptococcus species & 3 & 3 \\
\hline Peptostreptococcus species & 3 & 7 \\
\hline Bifidobacterium species & 2 & 0 \\
\hline Others & 8 & 14 \\
\hline
\end{tabular}

Number of pathogenic bacteria is greater than number of patients in each teatment group because some infections were polymicrobial

used. No statistically significant differences were found with the intention to treat analysis $(\mathrm{P}=0.88)$. Similar results were found when clinical efficacy was analyzed for cases with definite infections $(\mathrm{P}=0.81)$. Clinical responses were also evaluated according to site of infection, eg, abdomen or pelvis, without any differences found between the two treatment regimens. The 95\% confidence limits on the differences between treatment regimens for positive clinical outcomes (cured) in the total sample of 250 patients and in the 88 patients with definite infections were $-10.9 \%$ to $9.3 \%$ and $-21.6 \%$ to $14.8 \%$, respectively.

An analysis of clinical outcomes according to the McCabe Jackson rating of the patients' underlying disease showed no differences in cure rates between imipenem and clindamycin/tobramycin for patients with either nonfatal $(\mathrm{P}=0.88)$ or ultimately and rapidly fatal diseases $(\mathrm{P}=0.68)$.

For bacteriological response, the overall outcomes in the two treatment arms were compared. No statistically significant differences were found $(\mathrm{P}=0.81)$ (Table 4$)$. We also examined the success rates of imipenem and clin- 
TABLE 3

Clinical efficacy of imipenem-cilastatin versus clindamycin/tobramycin in 250 patients and in 88 patients with definite infections

\begin{tabular}{|c|c|c|c|c|}
\hline \multirow[b]{2}{*}{ Clinical response } & \multicolumn{2}{|c|}{ All patients } & \multicolumn{2}{|c|}{ Patients with definite infection } \\
\hline & $\begin{array}{l}\text { Imipenem-cilastatin } \\
(n=125)\end{array}$ & $\begin{array}{l}\text { Clindamycin/tobramycin } \\
\qquad(n=125)\end{array}$ & $\begin{array}{l}\text { Imipenem-cilastatin } \\
(n=41)\end{array}$ & $\begin{array}{l}\text { Clindamycin/tobramycin } \\
\qquad(\mathrm{n}=47)\end{array}$ \\
\hline Cured & $98(78.4)$ & $99(79.2)$ & $30(73.2)$ & $36(76.6)$ \\
\hline Improved & $12(9.6)$ & $19(15.2)$ & $5(12.2)$ & $8(17.0)$ \\
\hline Failed & $11(8.8)$ & $4(3.2)$ & $5(12.2)$ & $3(6.4)$ \\
\hline Relapse & $2(1.6)$ & $2(1.6)$ & $1(2.4)$ & $0(0)$ \\
\hline
\end{tabular}

Data are number (\%) of responses to antimicrobial therapy

\section{TABLE 4}

Bacteriological efficacy of imipenem-cilastatin versus clindamycin/łobramycin in 88 patients with definite infections

\begin{tabular}{lcc}
\hline $\begin{array}{l}\text { Bacteriological } \\
\text { response }\end{array}$ & $\begin{array}{c}\text { Imipenem- } \\
\text { cilastatin }(n=162)\end{array}$ & $\begin{array}{c}\text { Clindamycin/ } \\
\text { Tobramycin }(n=241)\end{array}$ \\
\hline $\begin{array}{l}\text { Eradication } \\
\text { Elimination with }\end{array}$ & $118(70.9)$ & $168(69.7)$ \\
recurrence & $17(10.5)$ & $42(17.4)$ \\
Persistence & $11(6.8)$ & $11(4.6)$ \\
Indeterminate & $16(9.9)$ & $20(8.3)$ \\
\hline
\end{tabular}

Data are number $(\%)$ of responses to antimicrobial therapy

damycin/tobramycin with respect to eradication of specific pathogens in the 88 cases of definite infection; no statistically significant differences were noted.

Eleven (8.8\%) and 15 (12.0\%) patients in the imipenem and clindamycin/tobramycin arms, respectively, became colonized with bacterial organisms. Enterococcal colonization was noted in four of the 11 imipenem patients and in five of the 15 clindamycin/tobramycin patients. Fungal colonization was noted in six $(4.8 \%)$ and four $(3.2 \%)$ patients treated with imipenem and clindamycin/tobramycin, respectively. In all cases of fungal colonization, the organism was Candida albicans.

Five $(4.0 \%)$ patients given imipenem and seven (5.6\%) patients given clindamycin/tobramycin developed superinfections. In the imipenem group, one patient had a bacterial superinfection while the remaining four had superinfection with $C$ albicans. Oral candidiasis was noted in one case, intertriginous candida infection in the groin area was found in two cases and candidemia was documented in one patient. All the superinfections in the clindamycin/tobramycin study arm were bacterial.

Three organisms initially sensitive to the assigned study drugs developed resistance during therapy. In two patients in the imipenem arm, $E$ faecalis and Pseudomonas aeruginosa developed resistance to imipenem after 14 and 10 days of therapy, respectively. In the clindamycin/tobramycin arm, there was one instance in which an organism, B fragilis, developed resistance. This occurred after eight days of clindamycin/tobramycin treatment. Both of the imipenem treated cases were cured and the clindamycin/tobramycin case improved.

Adverse effects: Eighty-three adverse events of interest related to drug use were recorded in the 250 cases evaluable for toxicity; 47 in the imipenem group and 36 in the clindamycin/tobramycin group (Table 5). Adverse effects resulted in the discontinuation of antibacterial therapy in 13 patients; seven on imipenem and six on clindamycin/tobramycin. Each adverse effect was considered as being definitely, probably or unlikely related to the treatment drug used. Only those felt by the investigator to be definitely or probably related were included in the analysis. Comparisons of adverse effects listed in Table 5 showed statistically significant differences for nausea $(\mathrm{P}=0.02)$ and hepatotoxicity $(\mathrm{P}=0.05)$. Comparisons of other outcome measures of adverse events did not reveal any statistically significant differences between the two study regimens.

The most frequent adverse effects (in order of decreasing frequency) were hepatotoxicity, nausea and infusion site complications. In the four patients (3.2\%) receiving imipenem and one patient $(0.8 \%)$ receiving clindamycin/tobramycin who had prolonged prothrombin times, none had clinical evidence of bleeding.

As shown in Table 5, the incidence of nephrotoxicity was zero in the imipenem group and one $(0.8 \%)$ in the clindamycin/tobramycin group. To make sure that all possible nephrotoxicity events were captured, we relied not only on reporting by the investigators but a paired analysis of all creatinine values was also done using a computerized search of this data subset.

The 95\% confidence limits on the differences between regimens for the most frequent adverse effects were: hepatotoxicity, -12.8 to $-0.04 \%$; nausea, 1 to 13.4\%; and infusion site complications, -4.5 to $7.7 \%$.

\section{DISCUSSION}

These results show that parenteral imipenem administered in a dose of $500 \mathrm{mg}$ every $6 \mathrm{~h}$ is as efficacious as the combination regimen clindamycin plus tobramycin given every 6 and $8 \mathrm{~h}$, respectively, for the treatment of intra-abdominal and pelvic infections. This was true for patients with possible infections as well as for those with definite infections. 
The clinical response rates in this study with imipenem and the control arm employing combination therapy were similar to those reported by other investigators. Positive response rates for imipenem and comparative control arms using combination regimens were: imipenem (93.7\%) versus clindamycin/netilmicin (89\%) (17); imipenem (91\%) versus cefotaxime/metronidazole/cloxacillin (94\%) (18); and impenem (87.5\%) versus clindamycin/gentamicin (80\%) (1).

An interesting study using the same treatment regimens as our trial found a significant improvement in outcome for the imipenem-cilastatin treated patients $(\mathrm{P}=0.04)$. This difference appeared to be due to a higher failure rate seen in patients with Gram-negative infection who were treated with clindamycin/tobramycin $(\mathrm{P}=0.018)$ (19).

We found no differences in the demographic and prognostic characteristics of the patients, and clinical outcomes for cure rates did not differ according to the McCabe Jackson rating of underlying disease. However, a shortcoming of our study is that we did not use the APACHE II system. Solomkin et al (19) used this method which essentially allows the investigator to describe the severity of illness of the patients and allows for a more balanced comparison of control and experimental groups.

Examination of the microbiological data showed no significant differences between the two treatment groups. The data showed no differences in the overall outcomes for aerobic Gram-positive cocci, Gram-negative bacilli and anaerobes, nor were differences found when the organisms were examined individually. Given the in vitro activity of imipenem and the control arm (clindamycin plus tobramycin) as well as the clinical response data from the studies mentioned above, the absence of significant differences between these two regimens for clinical and bacteriological outcomes is not surprising. Imipenem has an exceptionally broad spectrum of activity providing coverage against the main pathogens that one is likely to encounter in a patient with intra-abdominal and pelvic infection (20, 21). For most Gram-negative bacilli, with the exception of $P$ aeruginosa, the minimal bactericidal concentration is usually similar to the minimal inhibitory concentration (22). For the clinically important anaerobes in this setting, imipenem is as active in vitro as metronidazole or clindamycin (20). Intravenous imipenem is well distributed into most tissues and body fluids and only about $20 \%$ of the drug is protein bound (23).

Because of the very broad spectrum of activity seen with agents such as third generation cephalosporins and carbapenems, eg, imipenem, concern has been expressed about possible colonization and superinfection with various organisms. Particular concern has focused on enterococci and fungi. In the past, high rates of enterococcal colonization have been reported with moxalactam $(24,25)$. In a previous study compar-
TABLE 5

Adverse drug effects in 250 patients treated with imipenem-cilastatin or clindamycin/tobramycin

\begin{tabular}{|c|c|c|}
\hline \multirow[b]{2}{*}{ Adverse events } & \multicolumn{2}{|c|}{ Number $(\%)$ of events in treatment group } \\
\hline & $\begin{array}{l}\text { Imipenem- } \\
\text { cilastatin } \\
(n=125)\end{array}$ & $\begin{array}{l}\text { Clindamycin/ } \\
\text { tobramycin } \\
(n=125)\end{array}$ \\
\hline Nephrotoxicity & $0(0)$ & $1(0.8)$ \\
\hline Erythema, pruritis & $1(0.8)$ & $1(0.8)$ \\
\hline Nausea & $13(10.4)$ & $4(3.2)$ \\
\hline Vomiting & $3(2.4)$ & $3(2.4)$ \\
\hline Diarrhea & $3(2.4)$ & $4(3.2)$ \\
\hline $\begin{array}{l}\text { Pseudomembranous } \\
\text { colitis }\end{array}$ & $0(0)$ & $1(0.8)$ \\
\hline Hepatotoxicity & $5(4.0)$ & $13(10.4)$ \\
\hline $\begin{array}{l}\text { Elevation in } \\
\text { prothrombin time }\end{array}$ & $4(3.2)$ & $1(0.8)$ \\
\hline Positive Coombs' test & $0(0)$ & $0(0)$ \\
\hline $\begin{array}{l}\text { Infusion site } \\
\text { complications* }\end{array}$ & $9(7.2)$ & $7(5.6)$ \\
\hline Dizziness & $2(1.6)$ & $0(0)$ \\
\hline Headache & $6(4.8)$ & $1(0.8)$ \\
\hline Vertigo & $1(0.8)$ & $0(0)$ \\
\hline Seizures & $0(0)$ & $0(0)$ \\
\hline
\end{tabular}

"Infusion site complications include phlebitis, local cellulitis and burning or pain on administration

ing ceftriaxone with cefotaxime in patients with serious bacterial infections, we found colonization rates of $4.1 \%$ and $3.4 \%$ in the ceftriaxone and cefotaxime groups, respectively (26).

In the present study, the incidences of bacterial colonization were $8.8 \%$ for imipenem and $12.0 \%$ for clindamycin/tobramycin. When enterococcal and fungal colonization specifically were compared in the two arms, no significant differences were noted.

The incidence of superinfection was $4 \%$ for imipenem and $5.6 \%$ for clindamycin/tobramycin. Superinfection rates in studies with imipenem for treatment of infection in a variety of sites have ranged from 0 to $15 \%$ $(27,28)$. In Solomkin's earlier study of imipenem (9), the superinfection rate in the imipenem study arm was 13.5\% (five of 37 patients).

Generally, development of resistance to imipenem is uncommon for most bacteria with the possible exception of $P$ aeruginosa (29). This experience is certainly borne out in this trial. Of a possible 162 bacteria in the imipenem arm, only two (1.2\%) became resistant. Resistance development in the clindamycin/tobramycin arm was exceedingly low, with only one organism $(0.4 \%), B$ fragilis, becoming resistant to clindamycin.

Both imipenem and clindamycin/tobramycin were generally well tolerated. The only statistically significant differences were seen with nausea and hepatotoxicity. The former was seen more frequently with imipenem (10.4\% versus $3.2 \%$ ) whereas the latter was encountered more frequently with clindamycin/to- 
bramycin (10.4\% versus $4 \%)$. These results are certainly consistent with other reports in the literature $(29,30)$. Generally, the most common adverse experiences with most beta-lactams are those involving the gastrointestinal tract, particularly nausea, vomiting and diarrhea (29). While vomiting and diarrhea occurred with equal frequency in the two study arms in this trial, nausea was reported more frequently with imipenem.

What was particularly surprising was the low incidence of nephrotoxicity seen with clindamycin/tobramycin $(0.8 \%)$. Usually, the incidence of nephrotoxicity with aminoglycosides is higher although in the study by Hackford (1), the incidence of nephrotoxicity was only $4 \%$ for patients treated with clindamycin/gentamicin. A study of antimicrobial management of febrile neutropenic patients done in Canada compared a double beta-lactam with a standard beta-lactam plus aminoglycoside regimen (31). An unexpected finding was the

ACKNOWLEDGEMENTS: The authors gratefully acknowledge the financial support of Merck Frosst Canada, the technical assistance of Gordon Krip, PhD, Kevin Darbyson, BSc, and Guy Boisvert in processing the data, and Gail Matthias for manuscript preparation. The authors are also indebted to their colleagues in the Canadian Clinical Trials Group: Dr P Auger, Montreal, Quebec; Dr RT Chan, Vancouver, British Columbia; Dr JM Conly, Saskatoon, Saskatchewan; Dr E Crichton, Vancouver, British Columbia; Dr J Dubois, Sherbrooke, Quebec; Dr Dylewski, Montreal, Quebec; Dr IW Fong, Toronto, Ontario; Dr M Gourdeau, Quebec City, Quebec; Dr D Haase, Halifax, Nova Scotia; Dr GKM Harding, Winnipeg, Manitoba; Dr F Lebel, Montreal, Quebec; Dr B Mederski, Willowdale, Ontario; Dr EC Perry, Ottawa, Ontario; Dr M Poisson, Montreal, Quebec; Dr A Rachlis, Toronto, Ontario; Dr R Saginur, Ottawa, Ontario; Dr CK Wong, New Westminster, British Columbia.

\section{REFERENCES}

1. Hackford AW, Tally FP, Reinhold RB, Barza M, Gorbach SL. Prospective study comparing imipenem-cilastatin with clindamycin and gentamicin for the treatment of serious surgical infections. Arch Surg 1988;123:322-6.

2. Lorber B, Swenson RM. The bacteriology of intraabdominal infections. Surg Clin North Am 1975;55:1349-54.

3. Eschenbach DA, Buchanan TM, Pollack HM, et al. Polymicrobial etiology of acute pelvic inflammatory disease. N Engl J Med 1975;293:166-72.

4. Sweet RL. Imipenem/cilastatin in the treatment of obstetric and gynecologic infections: A review of worldwide experience. Rev Infect Dis 1985;7(Suppl 3): S522-7.

5. Kager L, Nord CE. Imipenem/cilastatin in the treatment of intraabdominal infections: A review of worldwide experience. Rev Infect Dis 1985;7(Suppl 3):S518-21.

6. Bartlett JG, Miao PVW, Gorbach SL. Empiric treatment with clindamycin and gentamicin of suspected sepsis due to anaerobic and aerobic bacteria. J Infect Dis 1977; 135(Suppl):80-5.

7. Smith JA, Foward AD, Skidmore AG, Bell GA, Murphy JM. Metronidazole and tobramycin in intraabdominal sepsis. Surg Gynecol Obstet 1982;155:235-7.

8. Gall SA, Kohan AP, Ayers CM, Hughes CE, Addison WA, very low incidence of nephrotoxicity encountered in the aminoglycoside arm (2.3\%). Two possible reasons for the low incidence of nephrotoxicity in the present study may be the relatively short duration of therapy 18.5 days) and the close monitoring of serum aminoglycoside levels.

Our data support the conclusion that monotherapy with imipenem administered in a dose of $500 \mathrm{mg}$ every $6 \mathrm{~h}$ is as efficacious as the combination regimen of clindamycin plus tobramycin for the treatment of intraabdominal and pelvic infections. When evaluating costs of the two regimens, it is not only acquisition costs that should be considered. Imipenem is given every $6 \mathrm{~h}$, whereas the combination regimen requires the administration of clindamycin every $6 \mathrm{~h}$ and tobramycin every $8 \mathrm{~h}$. This fact alone has implications in terms of pharmacy and nursing time. In addition, monitoring of aminoglycoside serum levels adds to the cost of these drugs and should be taken into account.

Hill GB. Intravenous metronidazole or clindamycin with tobramycin for therapy of pelvic infections. Obstet Gynecol 1981;57:51-8.

9. Solomkin JS, Fant WK, Rivera JO, Alexander JW. Randomized trial of imipenem/cilastatin versus gentamicin and clindamycin in mixed flora infections. Am J Med 1985;78(Suppl 6A):85-91.

10. Kropp H, Sundelof JG, Kahan JS, Kahan JS, Birnbaum J. MK0787 (N-formimidoyl thienamycin): Evaluation of in vitro and in vivo activities. Antimicrob Agents Chemother 1980; 17:993-1000.

11. Kropp H, Gerckens L, Sundelof JG, Kahan FM. Antibacterial activity of imipenem: The first thienamycin antibiotic. Rev Infect Dis 1985;7(Suppl 3):S389-410.

12. Geddes AM, Stille W. Imipenem: The first thienamycin antibiotic. Rev Infect Dis 1985;7(Suppl 3):S353-6.

13. McCabe WR, Jackson GG. Gram negative bacteremia: I Etiology and ecology. Arch Intern Med 1962;110:847-55.

14. Bauer AW, Kirby WMM, Sherris JC, Turck M. Antibiotic susceptibility testing by a standardized disk method. Am J Clin Pathol 1966;45:493-6.

15. National Committee for Clinical Laboratory Standards. M11-A. Reference agar dilution procedure for antimicrobial susceptibility testing of anaerobic bacteria. Villanova: National Committee for Clinical Laboratory Standards, 1985.

16. Smith CR, Lipsky JJ, Laskin OL, et al. Double-blind comparison of the nephrotoxicity and auditory toxicity of gentamicin and tobramycin. N Engl J Med 1980;302:1106-9.

17. Gonzenbach HR, Simmen HP, Amgwerd R. Imipenem (N-F-Thienamycin) versus netilmicin plus clindamycin. Ann Surg 1987;205:271-5.

18. Norwegian Study Group. Imipenem/cilastatin as monotherapy in severe infections: Comparison with cefotaxime in combination with metronidazole and cloxacillin. Scand J Infect Dis 1987; 19:667-75.

19. Solomkin JS, Dellinger EP, Christou NV, Busuttil RW Results of a multicenter trial comparing imipenem/ cilastatin to tobramycin/clindamycin for intraabdominal infections. Ann Surg 1989;212:581-91.

20. Barza M. Imipenem: First of a new class of beta-lactam antibiotics. Ann Intern Med 1985; 103:552-60.

21. Birnbaum J, Kahan FM, Kropp H, Macdonald JS. 
Carbapenems, a new class of beta-lactam antibiotics.

Am J Med 1985;78(Suppl 6A):3-21.

22. Neu HC, Labthavikul P. Comparative in vitro activity of $\mathrm{N}$-formimidoyl thienamycin (MK0787). Antimicrob Agents Chemother 1982;21:341-3.

23. Kahan FM, Kropp H, Sundelof JG, Birnbaum J. Thienamycin: Development of imipenem-cilastatin. J Antimicrob Chemother 1983;12:1-35.

24. Abbruzzese JL, Rocco LE, Laskin OL, Skubitz KM, McGaughey MD, Lipsky JJ. Prospective randomized double-blind comparison of moxalactam and tobramycin in treatment of urinary tract infections. Am J Med 1983;74:694-9.

25. Yu VL. Enterococcal superinfection and colonization after therapy with moxalactam, a new broad-spectrum antibiotic. Ann Intern Med 1981;94:784-5.

26. Mandell LA, Bergeron MG, Ronald AR, et al. Once-daily therapy with ceftriaxone compared with daily multiple-dose therapy with cefotaxime for serious bacterial infections: A randomized, double-blind study. $\mathrm{J}$ Infect Dis 1989;160:433-41.
27. Diaz-Mitoma F, Harding GKM, Louie TJ, Thomson M, James M, Ronald AR. Prospective randomized comparison of imipenem/cilastatin and cefotaxime for treatment of lung, soft tissue, and renal infections. Rev Infect Dis 1985;7(Suppl 3):452-7.

28. Guerra JG, Casalino E, Palomino JC, et al. Imipenem/ cilastatin vs gentamicin/clindamycin for the treatment of moderate to severe infections in hospitalized patients. Rev Infect Dis 1985;7(Suppl 3):463-70.

29. Wang C, Calandra GB, Aziz MA, Brown KR. Efficacy and safety of imipenem/cilastatin: A review of worldwide clinical experience. Rev Infect Dis 1985;7(Suppl 3):528-36.

30. Williams DN, Crossley K, Hoffman C, Sabath LD. Parenteral clindamycin phosphate: Pharmacology with normal and abnormal liver function and effect on nasal staphylococci. Antimicrob Agents Chemother 1975;7:153-8.

31. Feld R, Louie TJ, Mandell L, et al. A multicenter comparative trial of tobramycin and ticarcillin vs moxalactam and ticarcillin in febrile neutropenic patients. Arch Intern Med 1985; 145:1083-8. 


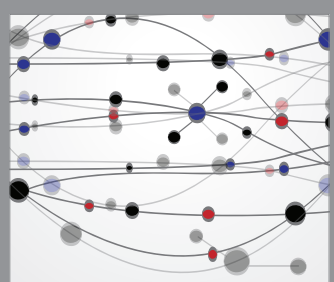

The Scientific World Journal
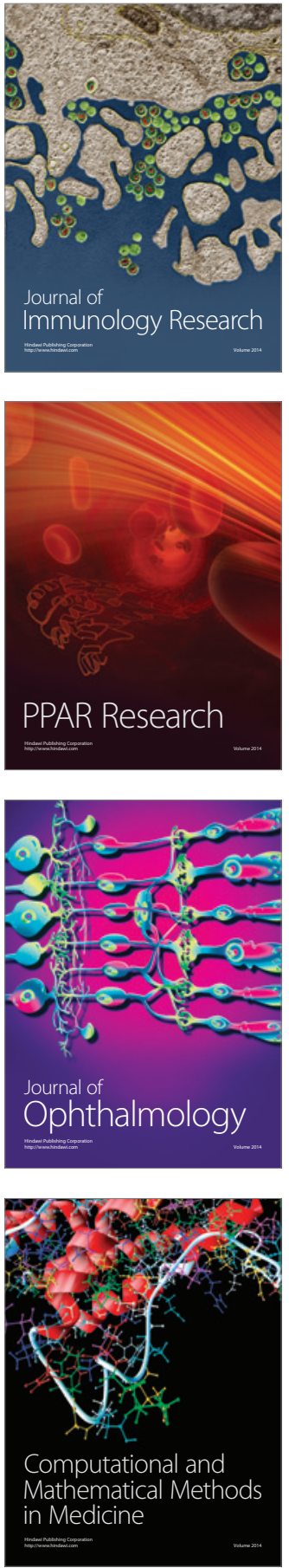

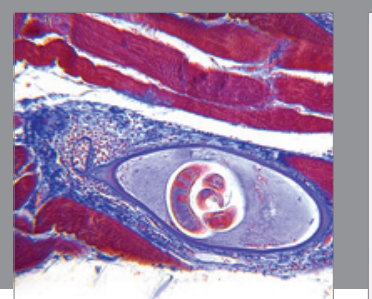

Gastroenterology Research and Practice

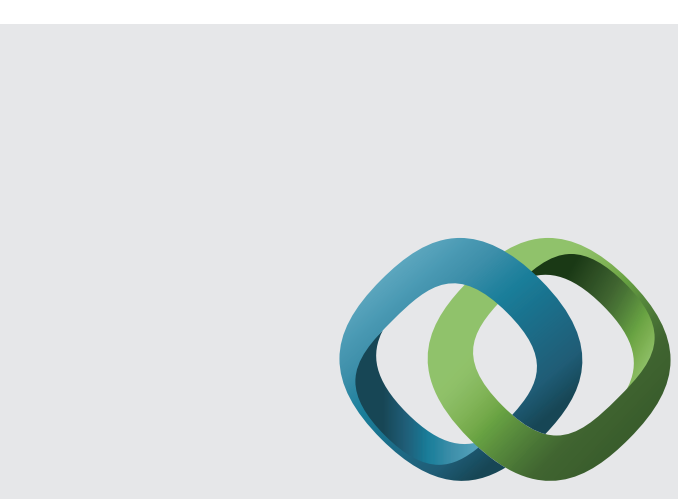

\section{Hindawi}

Submit your manuscripts at

http://www.hindawi.com
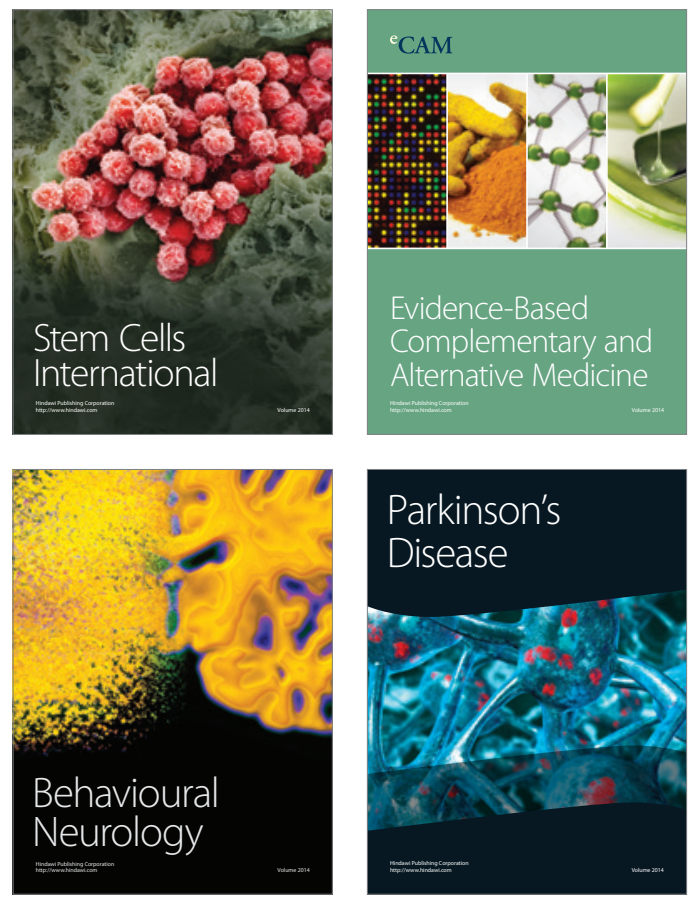
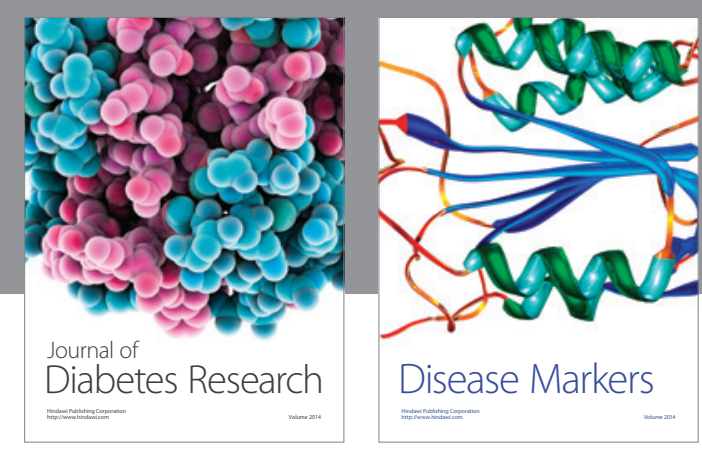

Disease Markers
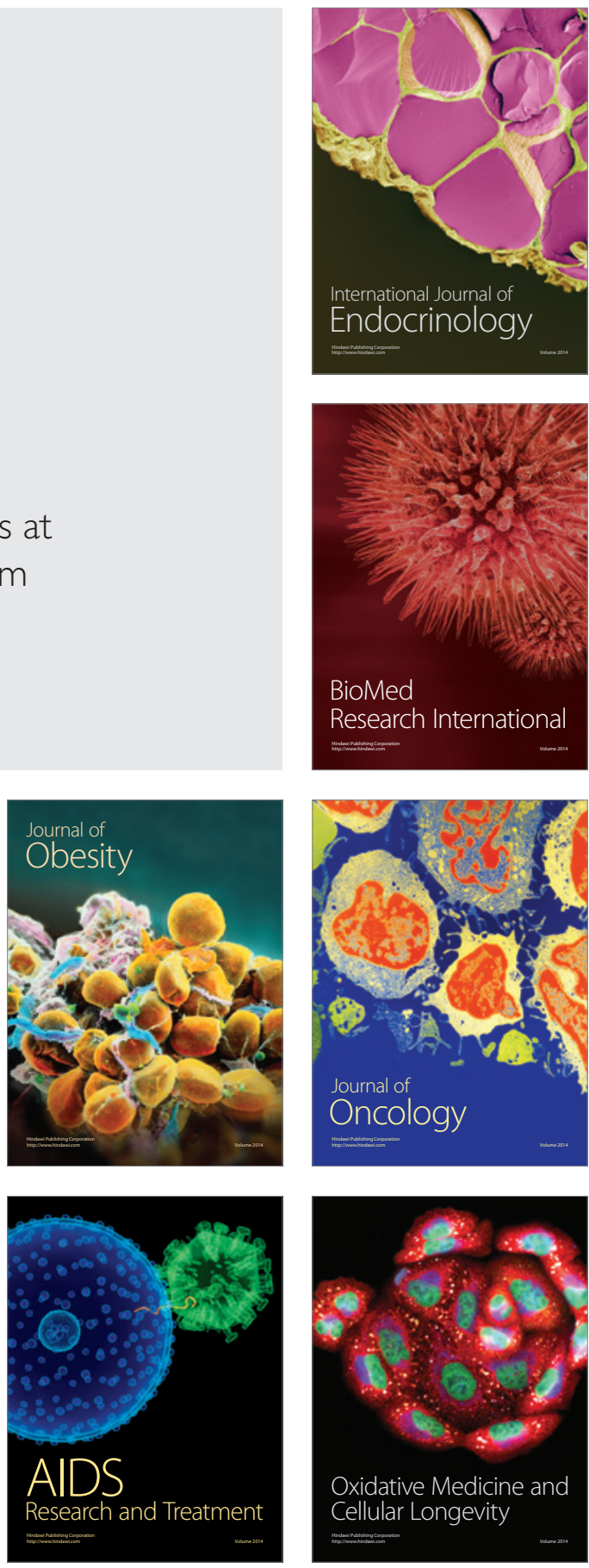